\title{
POP-UP: UNIVERSITY AND COMMUNITY COLLABORATIONS TOWARDS ADDRESSING YOUTH SUBSTANCE MISUSE
} \author{
SIERRA CASTEDO*, JULIE MCELRATH \\ *SCASTEDO@AUSTIN.UTEXAS.EDU; THE CENTER FOR STUDENTS IN RECOVERY AT THE UNIVERSITY OF TEXAS \\ AT AUSTIN, 2109 SAN JACINTO BLVD, E8000 BEL 222, AUSTIN, TX 78712
}

To cite this article: Castedo, S. \& McElrath, J. (2018). POP-UP: University and Community Collaborations Towards Addressing Youth Substance Misusey. Journal of Recovery Science, 1(2), c10. https://doi.org/10.31886/jors.12.2018.28

To link to this article: https://doi.org/10.31886/jors.12.2018.28

\begin{abstract}
This presentation shares the process and findings of a funded interdisciplinary project involving researchers engaging in the difficult integrative dialogues to incorporate findings from diverse areas of research and practice. This interdisciplinary project, part of the Pop-Up Institute initiative at UT Austin, brought together researchers, community partners, peers, and students for one year to foster the kind of collaborative deconstruction of silos that is essential to the progression of the addiction recovery field. Results, lessons learned, and future directions gleaned from the Pop-Up Institute's year of activities will be discussed during this presentation.
\end{abstract}

\section{ARS ACCREDITATION FRAMEWORK - SCHOOL ORGANIZATION}

\author{
JULIE MCELRATH* \\ *JMCELRATH@UHIGHSCHOOL.ORG; UNIVERSITYHIGH SCHOOL, 2007 UNIVERSITY AVENUE, AUSTIN, TX 78705
}

To cite this article: McElrath, J. (2018). ARS Accreditation Framework - School Organization. Journal of Recovery Science, 1(2), c10. https://doi. org/10.31886/jors.12.2018.29

To link to this article: https://doi.org/10.31886/jors.12.2018.29

\section{ABSTRACT}

This session will guide you through the step by step accreditation standards for running the business side of Recovery High Schools. Learn from the best as you navigate selecting the model, identifying leadership, energizing a Board of Directors, building community partners and much more. 1. Business Planning: How do high schools operate with a revised strategic business plan that provides for a reasonable level of organizational autonomy and is created for longterm survivability and viability, 2. Board of Directors: How does the school have a functional and involved Board of Directors?, 3. School Leadership: How does the school have a recognized and fully trained leader or leaders who operate with a level of autonomy and flexibility within the larger organizational system?, 4. Community Partnerships: How does the school establish collaborative partnerships with local schools, treatment centers, and other community resources to create a coordinated system of support?, 5 . Public Relations \& Privacy Issues: How does the school have a plan to promote the school and its programs while respecting the privacy and safety of its students and families?, and 6. Program Evaluation: How does the school regularly evaluate the academic and therapeutic programs for continuous program improvement?

All authors approve this manuscript and the original submission. The authors report no conflicts of interest. This work is licensed under the CC-BY license. 